\title{
次世代有機微細配線基板技術
}

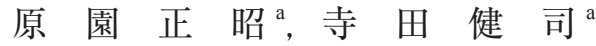 \\ a京セラサーキットソリューションズ(株) 技術開発本部 先進技術開発部 ( ₹ 520-2362 滋賀県野洲市市三宅 656)
}

\section{Organic Chip Carrier for Next Generation}

\section{Masaaki HARAZONO ${ }^{a}$ and Kenji TERADA ${ }^{a}$}

a Advanced Technology Development, Corporate Engineering and Development Group, KYOCERA Circuit Solutions, Incorporated(656, Ichimiyake, Yasu-shi, Shiga 520-2362)

Keywords : Build-Up, APX, 2.5D Interposer, HBM

\section{1.はじめに}

近年の高度情報化社会の急激な発展に伴い, 市場では半導 体部品の高機能化, 高速化, 小型化が急激に進んでいる。加 えて取扱うデー夕量は急速に増大化し, CPU/GPUなどに用 いられる半導体パッケージ基板には大容量のメモリ搭載が要 求されている。この市場要求に対応するために, 各社ではシ リコン基板代替技術として，ガラスや有機材上にビルドアッ プ工法を採用した半導体パッケージの開発が進んでおり, 一 部においては既に試作が開始されている。

本稿では, 従来のビルドアップ配線基板と次世代のビルド アップ配線基板, 及びその応用である有機 2.5D インターポー ザについて説明を行っていく。

\section{2. ビルドアップ配線基板}

ビルドアップ配線基板は高密度な有機配線基板の一つであ り, ガラスエポキシ基材の両面に絶縁層と導体層を交互に配 することで多層構造を形成している。この技術は 1990 年に 日本アイ・ビー・エム社が SLC (Surface Laminar Circuit ${ }^{\mathrm{TM}}$ )の 生産を始めて以来, 各社により様々な材料, 工法を使用した 有機ビルドアップ配線基板が展開され, ビアの微小径化, 配 線の微細化が進められてきた。図 1 に一般的な有機ビルド アップ配線基板の断面構造を示している。

ビルドアップ配線基板はスルーホール(以下, $\mathrm{TH}$ と称す),

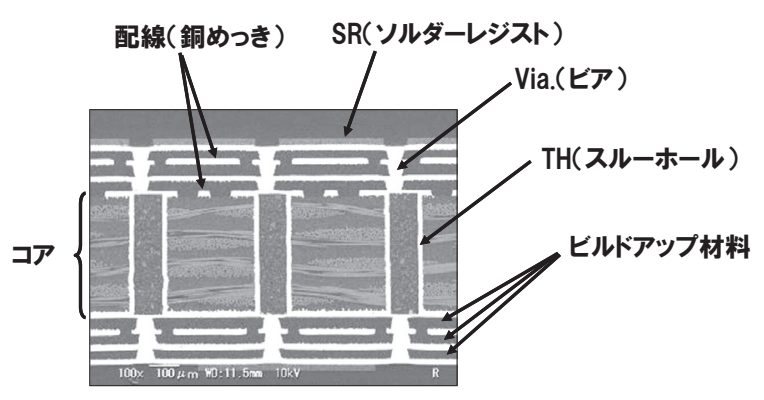

図 1 一般的な有機ビルドアップ配線基板
ビア，配線で構成され，図 2 で示すような技術変遷をたどり ながら, 現在も進化し続けている。

$\mathrm{TH}$ 形成では，コアとなるガラスエポキシ基材の表裏間を 電気的に接続させるために, ドリル, レーザ等で孔を開け, その後, 銅めっきによって表裏間の接続を行っている。ビア 形成では感光性材料を使用したフォトリソ加工，またはレー ザ加工で穴 (ビア)を開け, その後, 銅めっきによってビルド アップ層間の接続を行っている。
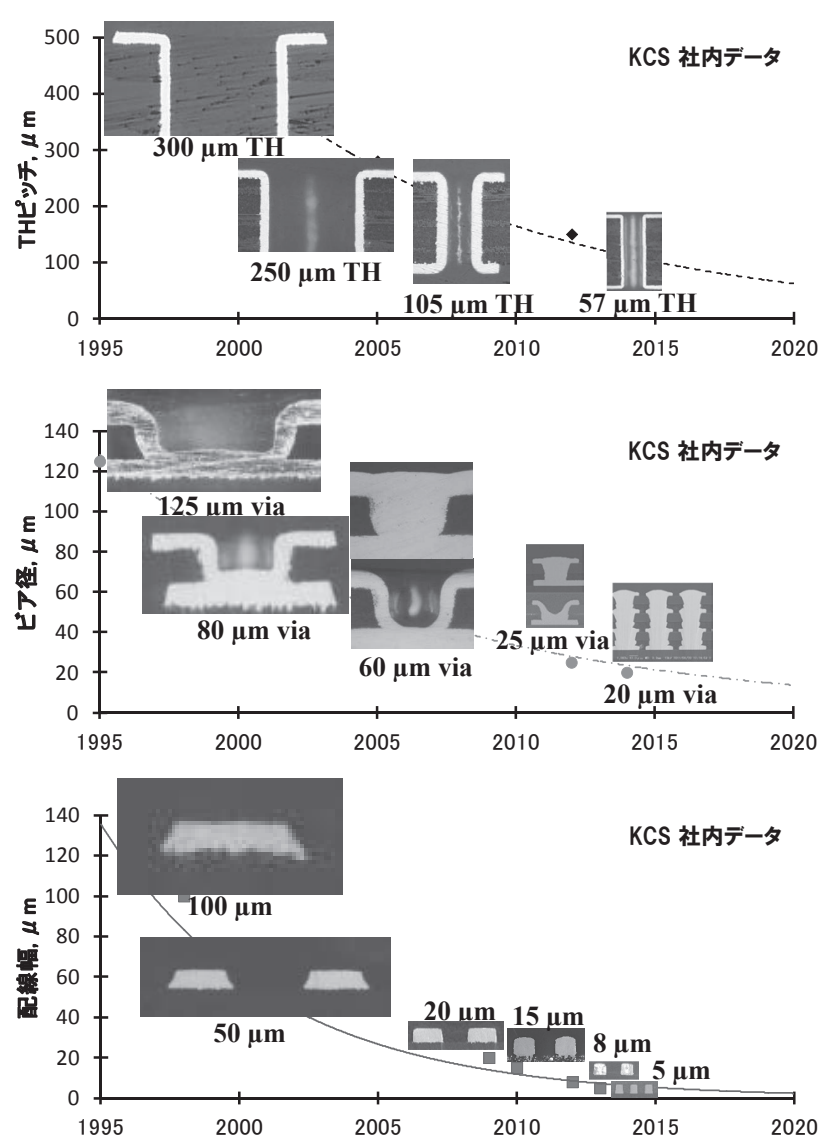

図2 THピッチ, ビア径, 配線幅の技術変遷 ${ }^{1)}$ 
配線形成では, 図 3 に示すサブトラクティブ法, セミアディ ティブ法が用いられている。これらの構成要素を微細化する ことで, パッケージの小型化, 高密度化が図られてきている。

\section{3. 次世代ビルドアップ配線基板への要求性能}

半導体チップが狭ピッチ, 微細化されていくことに対応す るためには, 次世代ビルドアップ配線基板も狭ピッチ, 微細 化しなければならないが, 同時に以下の性能を満足させる必 要がある。

次世代ビルドアップ配線基板に要求される性能として,

(1) 電気特性

$$
\begin{aligned}
& \text { ・シグナルインテグリティ } \\
& \text { ・パワーインテグリティ }
\end{aligned}
$$

(2) 信頼性

$$
\text { - 一次実装信頼性 }
$$

が挙げられる。それぞれの要求性能に対する対応手段を表 1 に示している。

電気特性で要求される項目に，シグナルインテグリティ並 びにパワーインテグリティがあり， シグナルインテグリティ の要求は Zo 整合とクロストークである。配線の微細化に対 応する為には，インピーダンス整合を図りながら絶縁層を薄 膜化し，パワー，グランド間の距離を短くしていかなければ ならない。また，クロストークノイズを低くするためには絶 縁層の薄膜化が必要である。

パワーインテグリティの要望は, 電源, グランドの安定化 であり, そのためにはビア, THの数を増やしていかなけれ ばならない。
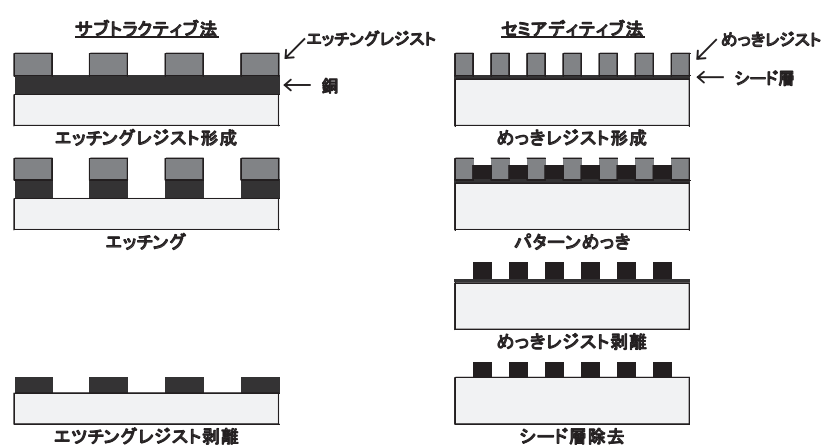

\begin{tabular}{|c|c|c|c|}
\hline \multicolumn{2}{|r|}{ 項目 } & 要求内容 & 対応手段 \\
\hline \multirow{4}{*}{ 電気特性 } & \multirow{3}{*}{$\begin{array}{c}\text { シグナルインテ } \\
\text { グリティ }\end{array}$} & \multirow{2}{*}{$Z_{0}$ 整合 } & 絶縁層の薄膜化 \\
\hline & & & 絶縁材料の低誘電率 \\
\hline & & クロストーク & 絶縁層の薄膜化 \\
\hline & $\begin{array}{c}\text { パワーインテグ } \\
\text { リティ }\end{array}$ & Max. $\pm 5 \%$ & Via， TH の数を増加する \\
\hline \multirow[b]{2}{*}{ 信頼性 } & 一次実装信頼性 & $\begin{array}{l}\text { JEDEC } \\
\text { Level.3 } \\
\end{array}$ & $\begin{array}{l}\text { 基板の低 CTE 化 } 3 \text { に近づ } \\
\text { ける }\end{array}$ \\
\hline & 二次実装信頼性 & $\begin{array}{l}\text { JEDEC } \\
\text { Level.3 }\end{array}$ & $\begin{array}{l}\text { CTE } 3-20 \mathrm{ppm} \text { の 間 で一次, } \\
\text { 二次接合を満足する接点を } \\
\text { 見出す }\end{array}$ \\
\hline
\end{tabular}

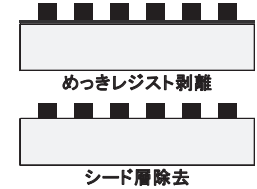

図 3 配線形成方法

表 1 次世代ビルドアップ配線基板要求への対応手段
信頼性で要求される項目に, 一次と二次の実装信頼性があ り，共に次世代ビルドアップ配線基板の熱澎張率 (CTE)に依 存する内容であると言ってよい。一次実装信頼性の対応手段 としてビルドアップ配線基板の低 CTE 化がある。CTE： $3 \mathrm{ppm} /{ }^{\circ} \mathrm{C}$ である半導体チップをビルドアップ配線基板に実装 する際， 半導体チップとビルドアップ配線基板の熱膨張率差 が大きければ，はんだ接合部に応力が集中してしまい，半導 体チップにホワイトバンプと呼ばれるセパレーションの発生 するリスクが増大する。そのため, 一次実装ではビルドアッ プ配線基板を半導体チップの CTE に近づけることが望ましい。

一方, 二次実装の観点からはビルドアップ配線基板の CTEを下げるべきではない。それは, 半導体チップをビル ドアップ配線基板を更に実装後にボードへの BGA 接続(二 次実装)を行う必要があるからである。

ボードの CTE は約 $20 \mathrm{ppm} /{ }^{\circ} \mathrm{C}$ と大きく, ビルドアップ配線 基板を低 CTE 化することによって，BGA二次はんだ部に応 力が集中し, 破壞を引き起こす恐れがある。そのため, 一次 実装と二次実装の接続信頼性が両立出来るように, ビルド アップ配線基板の CTE を $3 \sim 20 \mathrm{ppm} /{ }^{\circ} \mathrm{C}$ の範囲で, 接点を見 出さなければならない。

図 4 には二次実装を考慮した場合のビルドアップ配線基板 の応力シミュレーション結果を示している。ボードの CTE が現在使用されている $20 \mathrm{ppm} /{ }^{\circ} \mathrm{C}$ 前後である場合, 二次実装 の観点から有機半導体パッケージ基板としての CTEは $10 \mathrm{ppm} /{ }^{\circ} \mathrm{C}$ 以上であることが二次実装には望ましい。

\section{4. 次世代ビルドアップ配線基板}

当社で開発した次世代ビルドアップ配線基板 Advanced Package X (APX)について以下, 説明を行っていく。

4. 1 材料特性とデザインルール

現時点の材料物性とそのデザインルールをそれぞれ表 2,

表 3 に，構造は図 5 に示している。

デザインルールは最少配線幅 $6 \mu \mathrm{m}$, 最少スペース $6 \mu \mathrm{m}$, 最小 TH ピッチ $110 \mu \mathrm{m}$, ビア径 $20 \mu \mathrm{m}$ とし, ビアは最大 3 段(表裏)までスタックビア構造にすることができる。ビルド アップ配線基板としての CTE は 5-2-5 構造で $11 \mathrm{ppm} /{ }^{\circ} \mathrm{C}$ とし ている ${ }^{3)}$ 。

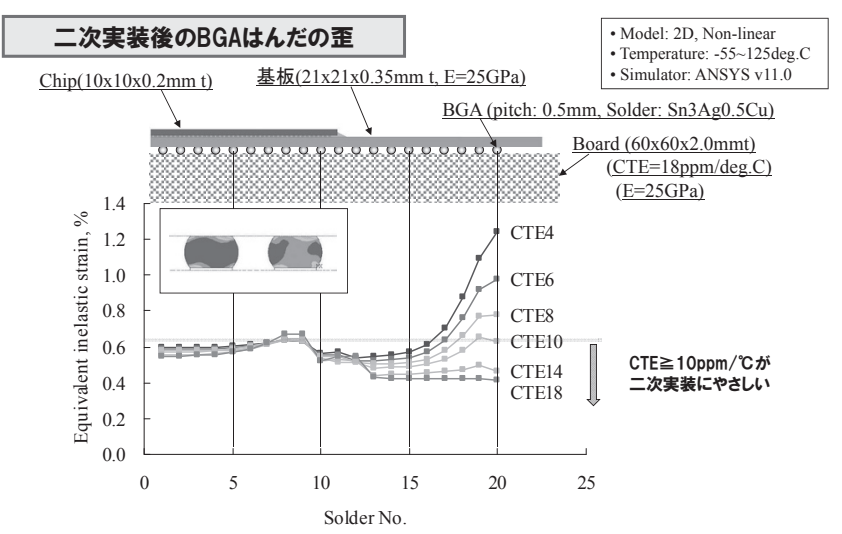

図 4 二次実装を考慮した配線基板の熱膨張率 ${ }^{1)}$ 
表 2 ビルドアップ材料の物性 ${ }^{2)}$

\begin{tabular}{|c|c|c|}
\hline \multicolumn{2}{|c|}{ Item } & Advanced Package X (APX) \\
\hline \multicolumn{2}{|l|}{ Loss tangent } & $0.0063 / 0.0066(2.8 \mathrm{GHz} / 10 \mathrm{GHz})$ \\
\hline \multicolumn{2}{|l|}{ Dielectric constant } & $3.1 / 3.1(2.8 \mathrm{GHz} / 10 \mathrm{GHz})$ \\
\hline CTE $x-y-z$ & TMA $(\mathrm{ppm} / \operatorname{deg} \mathrm{C})$ & $28(30-100$ degC) \\
\hline $\operatorname{Tg}$ & TMA (degC) & 150 \\
\hline Elongataion & $\%$ & $3.0-3.4$ \\
\hline Young's Modulus & $\mathrm{GPa}$ & $6.4-7.3$ \\
\hline Tensile Strength & $\mathrm{MPa}$ & $85-92$ \\
\hline Water Absorption & $\%$ & 0.2 \\
\hline
\end{tabular}

表 3 デザインルール 2 2)

\begin{tabular}{l|c}
\hline & Advanced Package X $($ APX $)$ \\
\hline Min. Line Width $(\mu \mathrm{m})$ & 6 \\
\hline Min. Space $(\mu \mathrm{m})$ & 6 \\
\hline Via Hole Diameter $(\mu \mathrm{m})$ & 20 \\
\hline Via Land Diameter $(\mu \mathrm{m})$ & 32 \\
\hline Max. number of Via Stack & 3 \\
\hline Build up Layer Thickness $(\mu \mathrm{m})(\mathrm{FVx} / \mathrm{BVx})$ & 8 \\
\hline Max. build up layer & 5 \\
\hline Max. Layer Count & $12(5-2-5)$ \\
\hline PTH Pitch $(\mu \mathrm{m})$ & 110 \\
\hline
\end{tabular}

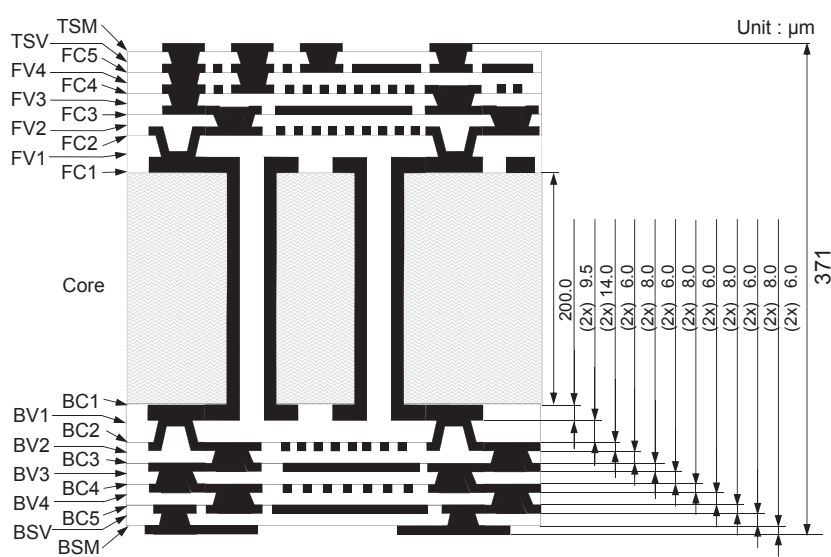

図 5 構造 ${ }^{2)}$

\section{2 プロセス}

次世代ビルドアップ配線基板は，表 4 に示すように，既存 のビルドアップ配線基板と同様なプロセスフローで形成して いく

ビア形成は $355 \mathrm{~nm}$ UVYAG レーザを使用し，シード層形成 は, 従来の無電解銅めっきに変えて, スパッタを採用している。

\section{3 構成要素}

図 6 に次世代ビルドアップ配線基板の技術要素である狭 ピッチ TH, 微細配線, 微小径ビア, 導体表面低粗化技術を 示している。

\section{3. 1 狭ピッチ $\mathrm{TH}$}

パワーインテグリティの強化を図るためにループインダク タンスの減少を図っている。コア厚を薄くすることで自己イ ンダクタンスが減少し, TH を狭ピッチ化することで相互イ ンダクタンスが増加する。図 7 に既存ビルドアップ配線基板 と APXのループインダクタンスの比較を示している。 TH ピッチを $110 \mu \mathrm{m}$ にまで狭ピッチ化させることで, 既存ビル ドアップ配線基板の $1 / 3$ にループインダクタンスを減少させ ることが可能となる。
表 4 プロセスフロー

\begin{tabular}{l|l}
\hline \multicolumn{1}{c|}{ 工程 } & \\
\hline 絶縁層形成 & フィルムラミネーション, 硬化 \\
\hline ビア形成 & レーザービア, プラズマ \\
\hline セミアディティブ & \\
\hline シード層形成 & スパッタ \\
\hline めっきレジスト形成 & ラミネート, 露光, 現像 \\
\hline 電気めっき & コンフォーマル, ビアフィル \\
\hline めっきレ゙スト剥離 & アミン剥離 \\
\hline シード層除去 & フラッシュエッチ \\
\hline 最終硬化 & \\
\hline 回路表面処理 & \\
\hline
\end{tabular}

Technology Feature of APX-2 ${ }^{\text {nd }}$

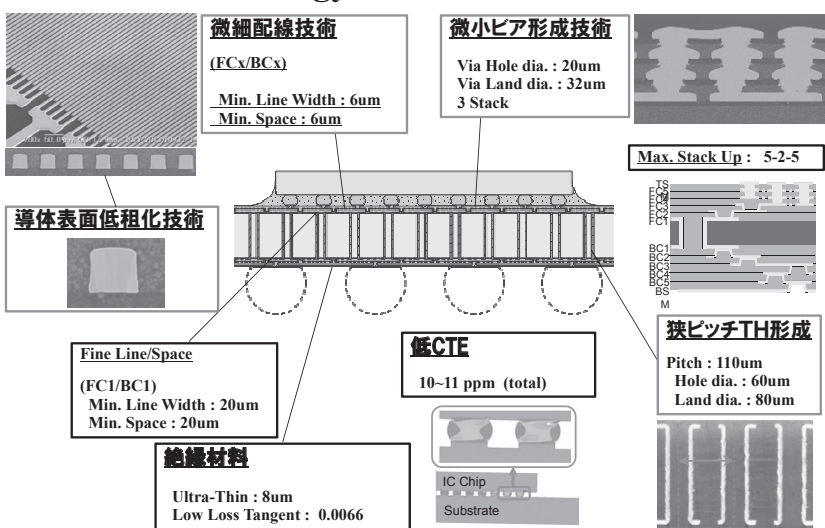

図6 技術要素 ${ }^{2)}$
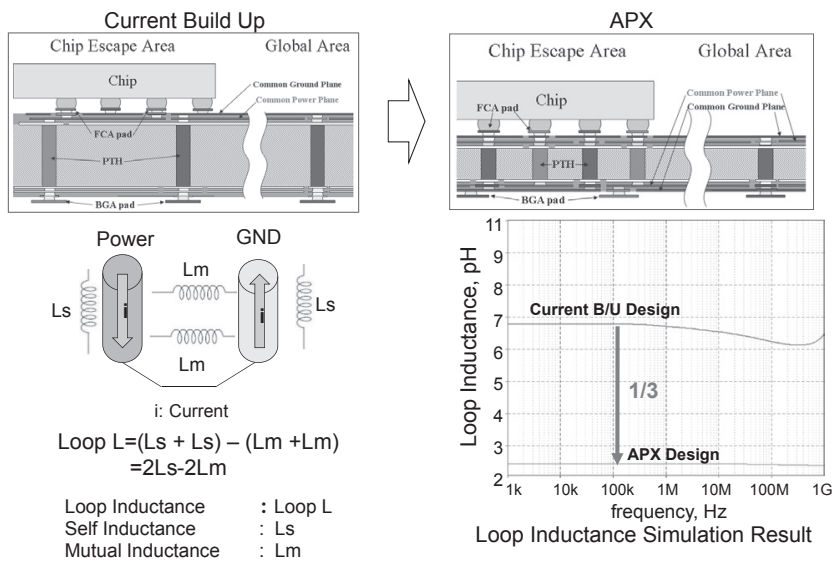

図7 ループインダクタンス比較 ${ }^{1)}$

\section{3. 2 微細配線, 微小ビア}

次世代ビルドアップ配線基板では, 更なる微細化が要求さ れてきている。当社では各プロセスの開発, 最適化を行うこ とで, $5 \mu \mathrm{m}$ ライン $/ 5 \mu \mathrm{m}$ スペースでの回路形成と信頼性を 図っている。現在 $6 \mu \mathrm{m}$ ライン $/ 6 \mu \mathrm{m}$ スペースのデザインを 用いた製品設計を積極的に提案している(図 8)。

絶縁層間は, $20 \mu \mathrm{m}$ ビア径, $32 \mu \mathrm{m}$ ビアランド径を用いた 微小ビアで接続する 3 段スタックまでの使用が可能である。

\section{3. 3 導体表面低粗化}

電気信号の伝搬においては，絶縁材料に起因する誘電損失 と導体に起因する導体損失の発生が問題となる。導体内を高 周波信号が伝搬する際に, 中心部の信号密度が減少するため に, 導体の外周部分での信号密度が集中していく表皮効果現 

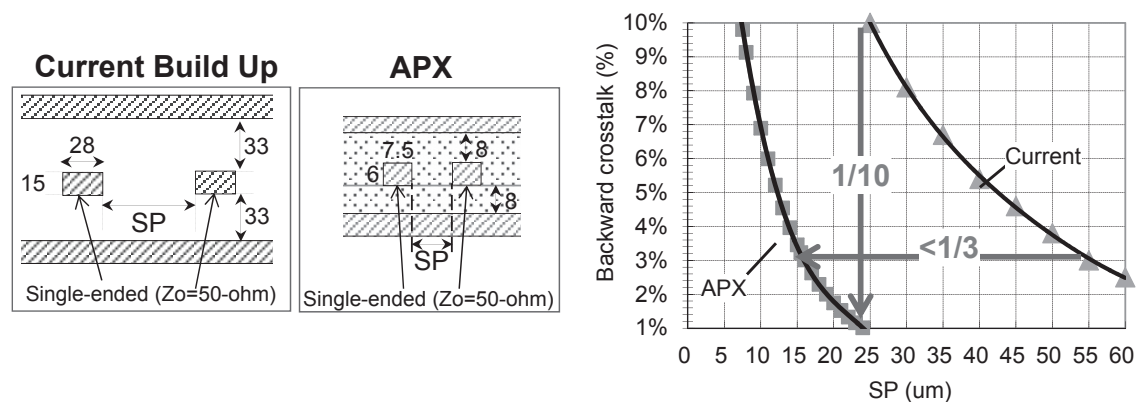

図 10 クロストークノイズ ${ }^{3)}$

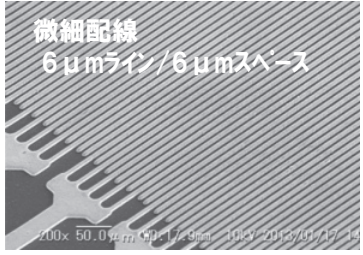

微細配線

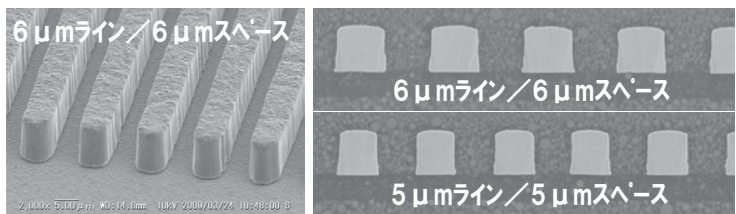

図8 微細配線, 微小ビア ${ }^{3)}$

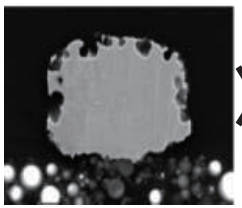

$\mathrm{Ra}=500 \mathrm{~nm}$

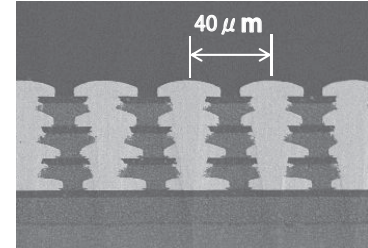

狭ピツチ微小ビア

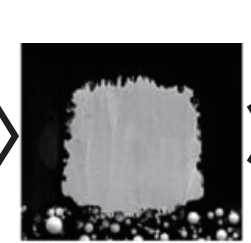

$\mathbf{R a}=\mathbf{2 0 0 n m}$

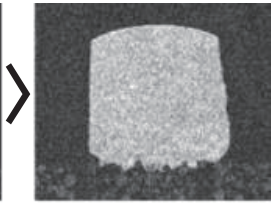

$R a=60 \mathrm{~nm}$
図 9 表面粗化後の導体断面観察 ${ }^{3)}$

象が発生してしまう。この現象は周波数が高くなるに伴い顕 著になっている。一般的なプリント配線板においては導体表 面と絶縁層樹脂との密着性を確保させるために，導体の表面 積を上げて物理的密着力を向上させる投錨効果(Anchor Effect）を用いた表面粗化処理が行われる。図 9 には表面粗化 後の導体断面の観察例を示している。次世代ビルドアップ配 線基板の導体表面は，下層絶縁材樹脂との界面，及び上層絶 縁樹脂との界面を平滑する処理によって平滑化が進み, 高周 波信号への対応を図っている。

4. 3. 4 クロストークノイズ

図 10 には既存有機ビルドアップ基板と APXのクロス トークノイズをシミュレーションで比較した結果を示してい る。クロストークノイズはビルドアップ樹脂膜厚に大きく依 存している。APXにおいては, 絶縁樹脂を薄膜化すること により既存のビルドアップ配線基板の $1 / 3$ のスペースでも同 一のクロストークノイズレベルが実現できる。

\section{4 信頼性}

表 5 に信頼性の試験項目と判定基準を示している。ビアに かかるストレスは図11のシミュレーション結果で示すよう
表 5 信頼性評価

\begin{tabular}{|c|c|c|c|}
\hline 試験名 & 加速条件 & 対象 & 判定基準 \\
\hline $\begin{array}{c}\text { DTC } \\
\text { (Dry Temperature } \\
\text { Cycling) }\end{array}$ & $\begin{array}{c}\Delta 180^{\circ} \mathrm{C} \\
\left(-55 / 125^{\circ} \mathrm{C}\right), \\
2 \mathrm{cph}\end{array}$ & クラック & $\begin{array}{c}\Delta \mathrm{R}<0.2 \Omega \text { or } 10 \% \\
\quad / 1000 \text { cycles }\end{array}$ \\
\hline $\begin{array}{r}\text { WTC }(※) \\
(\text { Wet TC) }\end{array}$ & $\begin{array}{c}\Delta 180^{\circ} \mathrm{C} \\
\left(-55 / 125^{\circ} \mathrm{C}\right), \\
10 \mathrm{cph}\end{array}$ & クラック & $\begin{array}{c}\Delta \mathrm{R}<0.2 \Omega \text { or } 10 \% \\
\quad / 1000 \text { cycles }\end{array}$ \\
\hline $\begin{array}{c}\text { PCBT }(※) \\
\text { (Pressure cooker } \\
\text { Bias Test) }\end{array}$ & $130{ }^{\circ} \mathrm{C} / 85 \mathrm{RH} \% 5 \mathrm{~V}$ & 絶縁性 & $\begin{array}{c}\mathrm{IR}>100 \mathrm{M} \Omega \\
\quad / 96 \mathrm{hrs}\end{array}$ \\
\hline $\begin{array}{c}\text { PCT } \\
\text { (Pressure cooker } \\
\text { Test) }\end{array}$ & $121{ }^{\circ} \mathrm{C}$ 100RH\% & 剥離性 & $\begin{array}{c}\mathrm{IR}>100 \mathrm{M} \Omega \\
\quad / 96 \mathrm{hrs}\end{array}$ \\
\hline $\begin{array}{c}\text { THB } \\
\text { (Temperature } \\
\text { Humidity Bias } \\
\text { Test) }\end{array}$ & $85^{\circ} \mathrm{C} / 85 \mathrm{RH} \% / 5 \mathrm{~V}$ & 絶縁性 & $\begin{array}{c}\Delta \mathrm{R}<0.2 \Omega \text { or } 10 \% \\
\quad / 1000 \text { cycles }\end{array}$ \\
\hline
\end{tabular}

(※)は Option

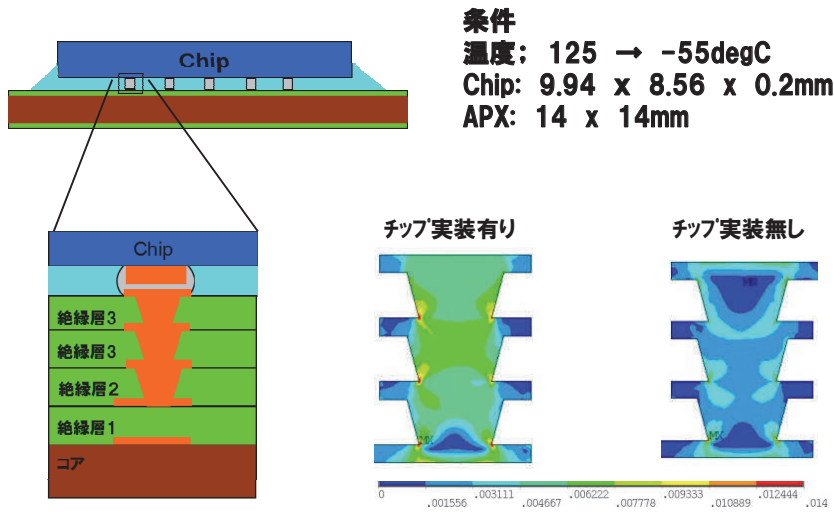

図11 ビアにかかるストレスシミュレーション例 ${ }^{3}$

にチップ実装の有無で大きく変わってしまう。特に，ビア径 の小径化に対しては, 有機配線基板単体の評価だけでは不十 分であり，チップを実装させた時の評価が重要となっている。

\section{2.5D インターポーザへのアプローチ}

\section{1 市場要求}

表 6 ではメモリの市場変遷を示している。その中で次世代 用のメモリとして, 高性能コンピュータ向けで広帯域に フォーカスした大容量メモリである HBM が注目されている。

\section{2 2.5D インターポーザの製品形態}

情報通信市場における次世代システムでは大容量メモリと CPUを最短接続したモジュールの要求が高まり, それに対 応するひとつの解として $2.5 \mathrm{D}$ インターポーザが有力視され 

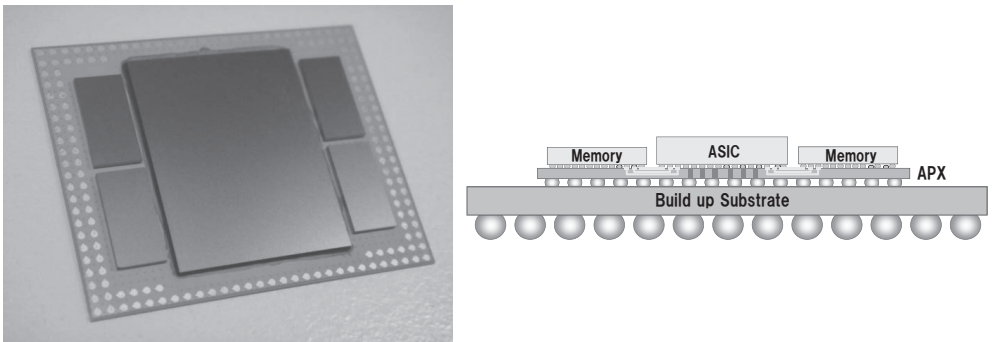

図 12 2.5D インターポーザ製品形態

表 6 メモリの市場変遷

\begin{tabular}{|c|c|c|c|c|}
\hline & 2014 & 2015 & 2016 & 2017 \\
\hline \multirow{2}{*}{ Server \& HPC } & \multicolumn{4}{|c|}{ HBN } \\
\hline & \multicolumn{4}{|c|}{ DDR4 } \\
\hline \multirow{2}{*}{ Graphics } & \multicolumn{4}{|c|}{$\mathrm{HBN}$} \\
\hline & \multicolumn{4}{|c|}{ GDDR5 } \\
\hline \multirow{2}{*}{ PC Memory } & \multirow{2}{*}{\multicolumn{3}{|c|}{ DDR3 }} & \multirow[b]{2}{*}{ DDR4 } \\
\hline & & & & \\
\hline \multirow{2}{*}{ Mobile } & \multicolumn{4}{|c|}{ Wide $\mathrm{I} / \mathrm{O} 2$} \\
\hline & \multicolumn{4}{|c|}{ LPDDR3 $\quad$ LPDDR4 } \\
\hline
\end{tabular}

ている。図 12 に2.5D インターポーザの製品形態を，図 13 では HBMメモリを 4 個搭載した $2.5 \mathrm{D}$ インターポーザの配 線例を示している。

次世代有機微細配線基板 Advanced Package X のデザイン ルールを用いることによって，5-2-5 構造で配線することが 可能である。

\section{6. 実装}

チップ実装には，リフロー方式とサーマルコンプレッショ ン $(\mathrm{TC})$ 方式の 2 種類がある。リフロー方式では，有機配線 基板パット部に半導体チップを接触させ, インラインオーブ ンの中で半導体・基板を同時に温度上昇させながら，はんだ を溶融させて接続を行う。はんだ融点に達するまで，基板と チップは同様に加熱される。一方, サーマルコンプレッショ ン方式では基板とチップをそれぞれ別々の温度で加熱する。 基板温度はチップ温度に比べて低温にすることが可能となり, 有機配線基板に対する狭ピッチチップ実装として期待される。

\section{7.おわりに}

近年, 進化し続ける情報通信機器並び端末の回路基板に対 する要求は留まるところを知らない。今後も, 更なる信号の
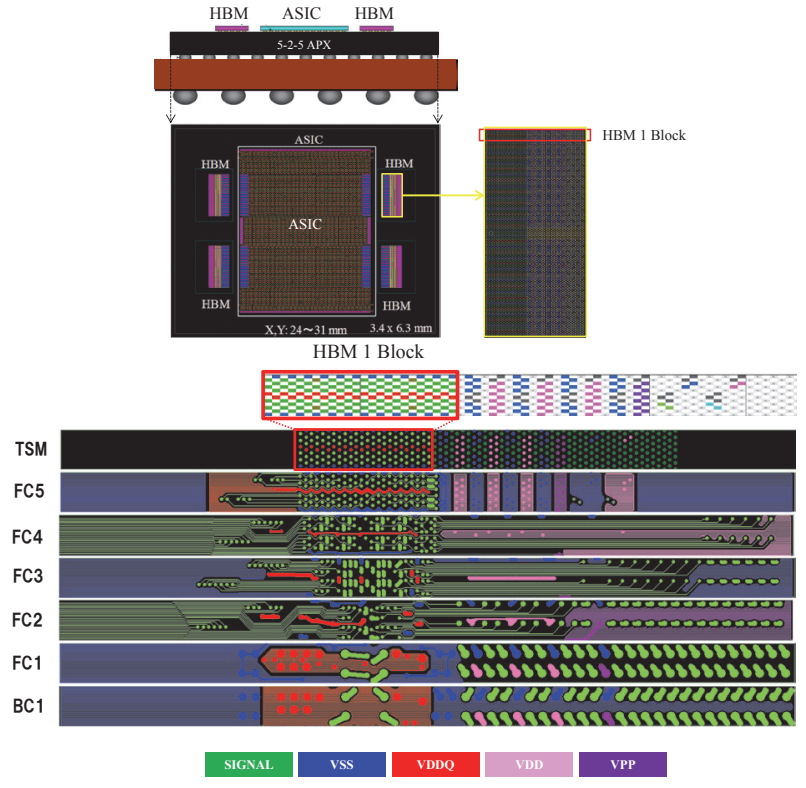

図13 HBMメモリへの配線例 ${ }^{3)}$

高速化並びに配線の微細化は求められているが，有機回路基 板技術はそれに伴って進化させていくことが出来ると確信し ている。

当社は今後も Low cost 材料\& Low Cost プロセスで, 次世代 の有機基板技術を実現していく。

(Received January 13, 2015)

\section{文献}

1 ) 福井雅弘2012 J-PWB EXPO (2012)

2 ) 石田光也 ; 2014エレクトロニクス実装学会シンポジウム (2014)

3 ) 寺田健司; MES2014講演要旨集. p411 (2014) 